\title{
Effect of Intercropping Wheat with Faba Bean on Wheat Productivity under Sandy Soil Conditions
}

\author{
Badran, M.S.S. ${ }^{1}$
}

\begin{abstract}
Two field experiments were carried out at the Experimental Station Farm of the Faculty of Agriculture, Damanhour University, El-Bostan Region, El-Behera Governorate, Egypt, during 2009/2010 and 2010/2011 winter growing seasons. This study aimed to invest?tigate the effect of four Egyptian wheat cultivars (Giza 168, Sakha 94, Gemmiza 9 and Sids 1), as well as six intercropping patterns of wheat with faba bean on wheat productivity under sandy soil conditions. The six intercropping patterns were: solid sowing of wheat at the three seeding rates, 300,350 and 400 grains $\mathrm{m}^{-2}$ and/or intercropped with Sakha1 faba bean cultivar by (1:1) alternate rows, $20 \mathrm{~cm}$ apart. A split-plot design with four replications was used in each experiment. The wheat cultivars occupied the main plots while, the intercropping patterns were arranged in the sub-plots. The most important obtained results can be summarized as follows:
\end{abstract}

Wheat cultivars were significantly different in most studied traits, except for plant height, biological yield ha ${ }^{-1}$, straw yield $\mathrm{ha}^{-1}$ and harvest index (\%) traits, in both seasons. Giza 168 cultivar surpassed the other three studied cultivars in grain yield $\mathrm{ha}^{-1}$ and its components in terms of spike length (cm), number of grains spike ${ }^{-1}$, number of spikes $\mathrm{m}^{-2}$ and 1000 -grain weight $(\mathrm{g})$, in both studied seasons.

The solid plantings of wheat had the highest significant means of grain yield ha ${ }^{-1}$ and its studied components in terms of spike length $(\mathrm{cm})$, number of spikelets spike $^{-1}$, number grains spike ${ }^{-1}$, number of spikes $\mathbf{m}^{-2}$, biological yield $\mathrm{ha}^{-1}$, straw yield $\mathrm{ha}^{-1}$ and 1000-kernel weight (g), in both seasons, compared to intercropping treatments.

Planting wheat solely at the low seeding rate; i.e., 300 grains $\mathrm{m}^{-2}$ was significantly different compared with the sole wheat plantings, seeded with the higher rates; i.e., 350 plus 400 grains $\mathrm{m}^{-2}$ for most studied traits, in both seasons, except for spike length, biological yield (in the second season), number of grains spike ${ }^{-1}$, number of spikes $\mathrm{m}^{-2}$, straw yield $\mathrm{ha}^{-1}$, harvest index $(\%)$ and 1000 -grain weight $(g)$, in both seasons. On the contrary, plant height character of solid wheat plants (in both seasons) was significantly decreased under the low seeding rate, 300 grains $\mathrm{m}^{-2}$, compared to wheat solid planting, but, seeded wheat with the higher seeding rates; i.e., 350 plus 400 grains $\mathbf{m}^{-2}$.

All studied traits were not significantly affected (in both seasons) by increasing seeding rates for solid wheat plantings from 350 to 400 grains $\mathrm{m}^{-2}$, except for the number of grains spike $e^{-1}$ that was significantly decreased from 32.28 to 30.38, averaged in both seasons.

Intercropped wheat, with faba bean by planting wheat at a seed rate of 300 grains $\mathrm{m}^{-2}$ significantly increased both spike length, from 10.42 to $11.14 \mathrm{~cm}$, and number of spikelets spike $^{-1}$, from 12.44 to 14.17 , averaged in the two studied seasons, compared with intercropped wheat with faba bean, but, seeded wheat with the higher seeding rates; i.e., 350 plus 400 grains $\mathrm{m}^{-2}$. Regarding the other studied traits, they were statistically similar in both seasons for both treatments.

Intercropped wheat with faba bean by seeded wheat with 400 grains $\mathrm{m}^{-2}$ insignificantly decreased all studied traits in both seasons, except for both plant height and harvest index, compared with intercropped wheat with faba bean by seeding wheat with 350 grains $\mathrm{m}^{-2}$.

A significant interaction was detected between wheat cultivars and intercropping patterns $\left(\mathrm{VxC}_{1}\right)$ for the number of spikelets spike ${ }^{-1}$ and grain yield $\mathrm{ha}^{-1}$ in the first season.

Intercropping Sakha 1 faba bean cultivar at 166667 plants ha ${ }^{-1}$ with Giza 168 wheat cultivar seeded with the rate of 350 grains $\mathrm{m}^{-2}$ in (1:1) alternate rows, $20 \mathrm{~cm}$ apart, under El-Bostan Region conditions, could be advised to obtain a high productivity of wheat.

Key words: Wheat cultivars, intercropping patterns, solid plantings, seeding rates.

\section{INTRODUCTION}

Wheat is the main cereal crop in the world, as well as in Egypt. Wheat provides more than one-third of the daily calorie intake of consumers and $45 \%$ of their total daily protein consumption (Rowntree, 1993 and Abdel Ghaffar, 1994). The gap between the national needs and the local wheat production was estimated by about 4.73 million tons yearly, which represent about $36.38 \%$ of the national production (Darwish et al., 2008). So, Egypt ranked the second among the world countries in importing wheat (Aboushal and Mahmoud, 2009). A great attention of several investigators has been directed to increase the productivity of wheat to minimize the gap between the Egyptian production and consumption, through increasing unit land area productivity and increasing planted area, particularly, using intercropping with other crops. Intercropping wheat with faba bean may be considered as one of the methods to increase the growing wheat area, horizontally, where,

\footnotetext{
${ }^{1}$ Crop Science Department, Faculty of Agriculture,

Damanhour University, Egypt

Received May 9, 2011, Accepted May 29, 2011
} 
the Egyptian planted land is limited (El-Monufi, 1984; Ali et al., 1986; Saleh et al., 1986; Abd- El-Gawad et al., 1988 and El-Metwally et al., 2002).

Seeding rate of wheat crop, in a mixture with faba bean, may be adjusted below its full rate. If the full rates of both crops were planted, neither would yield well because of overcrowding. Reducing the seeding rate of wheat may a chance wheat to yield well within the mixture. Accordingly, selecting the optimum wheat seeding rate, the suitable wheat cultivar and the intercropping pattern with faba bean which, produces high yields of both crops, under sandy soil conditions, was the aim of the present study.

\section{MATERIALS AND METHODS}

Two field experiments were carried out, during the two successive winter growing seasons of 2009/2010 and 2010/2011, at the Experimental Farm of the Faculty of Agriculture, Damanhour University, El-Bostan Region, El- Behera Governorate, Egypt, to study the performance of four Egyptian cultivars of wheat (Giza 168, Sakha 94, Gemmiza 9 and Sids 1) as well as six intercropping wheat with faba bean patterns, on wheat productivity under sandy soil conditions. The six intercropping patterns were as follows:

1-Sowing wheat as a sole crop at the rate of 300 grains $\mathrm{m}^{-2}\left(\mathrm{~W}_{1} \mathrm{~F}_{0}\right)$.

2-Sowing wheat as a sole crop at the rate of 350 grains $\mathrm{m}^{-2}\left(\mathrm{~W}_{\mathrm{m}} \mathrm{F}_{0}\right)$.

3-Sowing wheat as a sole crop at the rate of 400 grains $\mathrm{m}^{-2}\left(\mathrm{~W}_{\mathrm{h}} \mathrm{F}_{0}\right)$.

4-Intercropped wheat with faba bean at the rate of 300 grains of wheat $\mathrm{m}^{-2}\left(\mathrm{~W}_{1} \mathrm{~F}_{1}\right)$.

5-Intercropped wheat with faba bean at the rate of 350 grains of wheat $\mathrm{m}^{-2}\left(\mathrm{~W}_{\mathrm{m}} \mathrm{F}_{1}\right)$.

6-Intercropped wheat with faba bean at the rate of 400 grains of wheat $\mathrm{m}^{-2}\left(\mathrm{~W}_{\mathrm{h}} \mathrm{F}_{1}\right)$.

Soil samples, taken from the experimental site were mechanically analyzed (Piper, 1950) and are presented in Table (1).

A split-plot experimental design, with four replicates, was used in both seasons. The cultivars were randomly assigned to the main plots, while, the intercropping patterns were allocated in the sub-plots. The area of the sub-plot was $7.0 \mathrm{~m}^{2}$ (3.5 $\mathrm{m}$ long and 2.0 $\mathrm{m}$ wide), including ten rows, $20 \mathrm{~cm}$ apart, where wheat seeds were hand drilled, while, faba bean was handplanted in hills, in both seasons. Faba bean, Sakha 1 cultivar, was intercropped with wheat in (1:1) alternative rows. The plant population of faba bean was about 166667 plants $\mathrm{ha}^{-1}$. and was maintained through thinning seedlings to one plant hill ${ }^{-1}$, spaced at 30 and $15 \mathrm{~cm}$ for solid and intercropping treatments, respectively. Both crops were sown on $5^{\text {th }}$ Nov. in both seasons. Phosphorus fertilizer was broadcast during soil preparation in the form of calcium super phosphate $\left(15.5 \mathrm{P}_{2} \mathrm{O}_{5} \%\right)$ at the rate of $75.0 \mathrm{~kg} \mathrm{P}_{2} \mathrm{O}_{5} \mathrm{ha}^{-1}$. Potassium sulphate $\left(48 \% \mathrm{~K}_{2} \mathrm{O}\right)$ was side-dressed at the rate of $60.0 \mathrm{~kg} \mathrm{~K} \mathrm{O} \mathrm{ha}^{-1}$ before the first irrigation. Ammonium sulphate $(20.5 \% \mathrm{~N})$, at the rate of $240 \mathrm{~kg} \mathrm{~N} \mathrm{ha}^{-1}$, was added in three splits; namely, (1/5) broadcasted after sowing before irrigation and (4/5) was side-dressed at two equal doses before first and second irrigations. All other cultural practices were applied as recommended for wheat fields in El-Bostan Region.

Plants were harvested at 155 days from sowing, in both seasons, then ten random guarded wheat plants were taken from each sub-plot to calculate the following characters:

1- Plant height $(\mathrm{cm})$ : measured from ground surface up to the tip of stem spike. 2- Spike length (cm). 3Number of spikelets spike ${ }^{-1}$. 4- Number of grains spike ${ }^{-}$ 1

Also, a guarded length of one meter from the inner six rows of each sub-plot was harvested to determine the following traits:

5- Number of spikes $\mathrm{m}^{-2}$ : number of fertile tillers $\mathrm{m}^{-2}$ was calculated by counting all spikes per square meter.

6-Biological yield $\mathrm{ha}^{-1}$ : was recorded for the harvested area and converted to tons $\mathrm{ha}^{-1}$.

7-Grain yield $\mathrm{ha}^{-1}$ : was recorded for the harvested area after threshing and, then, converted to tons $\mathrm{ha}^{-1}$.

8-Straw yield $\mathrm{ha}^{-1}$ : the straw yield of the previous samples was estimated in $\mathrm{kg} \mathrm{m}^{-2}=$ [Biological yield $\left(\mathrm{kg} \mathrm{m} \mathrm{m}^{-2}\right)$ - grain yield $\left(\mathrm{kg} \mathrm{m} \mathrm{m}^{-2}\right)$, then, it was converted to tons $\mathrm{ha}^{-1}$.

9-1000-grain weight (g): recorded as the average of two random samples, each with 1000 clean grains.

10- Harvest index (H.I \%): calculated as follows: H.I $(\%)=($ Grain yield/Biological yield $) \times 100$.

Five orthogonal comparisons were done for intercropping patterns; i.e., $\mathrm{C}_{1}$ : Solid vs. intercropping wheat plantings; $\mathrm{C}_{2}$ : Low rate of solid wheat plantings vs. both the medium and high rates of solid wheat plantings $\left\{\mathrm{W}_{1} \mathrm{~F}_{0}\right.$ vs. $\left.\left(\mathrm{W}_{\mathrm{m}} \mathrm{F}_{0}+\mathrm{W}_{\mathrm{h}} \mathrm{F}_{0}\right)\right\} ; \mathrm{C}_{3}$ : The medium rate of solid wheat plantings vs. the high rate of solid wheat plantings $\left(\mathrm{W}_{\mathrm{m}} \mathrm{F}_{0}\right.$ vs. $\left.\mathrm{W}_{\mathrm{h}} \mathrm{F}_{0}\right) ; \mathrm{C}_{4}$ : The low rate of intercropped wheat and faba bean plantings vs. both the medium and high rates of intercropped wheat and faba bean plantings $\left\{\mathrm{W}_{1} \mathrm{~F}_{1}\right.$ vs. $\left.\left(\mathrm{W}_{\mathrm{m}} \mathrm{F}_{1}+\mathrm{W}_{\mathrm{h}} \mathrm{F}_{1}\right)\right\}$ and $\mathrm{C}_{5}$ : The medium rate of intercropped wheat and faba bean plantings vs. the high rate of intercropped wheat and 
Table 1. Soil mechanical analysis of the experimental sites in $2009 / 2010$ and $2010 / 2011$ growing seasons

\begin{tabular}{ccc}
\hline Characteristics & \multicolumn{3}{c}{ Seasons } \\
\cline { 2 - 3 } & $2009 / 2010$ & $2010 / 2011$ \\
\hline Sand (\%) & 77.37 & 74.25 \\
\hline Silt (\%) & 4.66 & 5.11 \\
\hline Clay (\%) & 17.97 & 20.64 \\
\hline Texture class & \multicolumn{3}{c}{} \\
\hline
\end{tabular}

faba bean plantings $\left(\mathrm{W}_{\mathrm{m}} \mathrm{F}_{1}\right.$ vs. $\left.\mathrm{W}_{\mathrm{h}} \mathrm{F}_{1}\right)$. On the other hand, the other five orthogonal comparisons were done for the interactions; i.e., $\mathrm{V} \times\left(\mathrm{C}_{1}, \mathrm{C}_{2}, \mathrm{C}_{3}, \mathrm{C}_{4}\right.$ and $\mathrm{C}_{5}$ ). The obtained data were statistically analyzed, according to (Steel and Torrie, 1980).

\section{RESULTS AND DISCUSSION}

\section{A-Wheat cultivars performance:}

Data of the grain yield $\mathrm{ha}^{-1}$ and its components of the four wheat cultivars; i.e., Giza 168, Sakha94, Gemmiza 9 and Sids 1, in 2009/2010 and 2010/2011 seasons, are presented in Tables (2 and 3). Data indicated that the four wheat cultivars were significantly different in the grain yield $\mathrm{ha}^{-1}$ and its studied components in both seasons, except for the plant height, biological yield ha ${ }^{-1}$, straw yield $\mathrm{ha}^{-1}$ and harvest index traits, where these traits were insignificantly affected by the studied wheat varieties in both studied seasons (Table 2). In this concern, many studies reported insignificant differences among wheat cultivars, regarding plant height (Shalaby et al., 1992; ElGenbeehy, 1994; Hassan, 2003 and Shalaby et al., 2009), biological yield and harvest index (El-Eryani, 1995 and Shalaby et al., 2009)and straw yield (ElGenbeehy, 1994). On the other hand, the data disagreed with those stated by other studies, which reported significant wheat cultivars differences, regarding plant height (Tabl et al., 2005); straw yield, biological yield and harvest index (Saleh, 2000; Moussa,2001;Ali et al., 2004; Tabl et al.,2005 and Badran ,2009. The difference between the present results and these ones may be due to the fact that they tested foreign along with Egyptian genotypes that differed in their genetic make up and their interaction with the environmental conditions prevailing during their growth.

Data presented in Table(3) showed that Giza 168 cultivar surpassed the other varieties in grain yield $\mathrm{ha}^{-1}$ and its components, in terms of spike length $(\mathrm{cm})$, number of grains spike ${ }^{-1}$, number of spikes $\mathrm{m}^{-2}$ and 1000-grain weight in both studied seasons. The differences in grain yield and its components among the evaluated four wheat varieties might be attributed to their genetic variations. Significant varietal differences in the literature, regarding these traits were reported
(Abdel-Hameed, 2002; Saleh, 2003; Ali et al., 2004; Abdel-Hameed, 2005 and Badran, 2009). Moreover, the other cultivars gave different mean values for the studied traits in both seasons.

\section{B- Intercropping patterns effect:}

The analysis of variance for the effect of intercropping patterns on grain yield and its studied components, in 2009/2010 and 2010/2011 seasons are presented in Table(2). The results showed either significant or highly significant effects for the six studied intercropping patterns on all studied traits, in both seasons, except for the harvest index character, in the second season, where the differences did not reach the level of significance.

Concerning the first comparison, $\mathrm{C}_{1}$; i.e., solid wheat plantings vs intercropping wheat with faba bean plantings, data in Table (2) indicated that almost highly significant differences were detected in both seasons between both treatments for all studied traits, except for harvest index character( in the second season). The solid wheat plantings had the highest means of grain yield ha ${ }^{-1}$ and its studied components, in terms of spike length $(\mathrm{cm})$, number of spikelets spike ${ }^{-1}$, number of grains spike ${ }^{-1}$, number of spike $\mathrm{m}^{-2}$; biological yield ha ${ }^{-1}$; straw yield $\mathrm{ha}^{-1}$ and 1000- kernel weight (g), in both seasons, compared to intercropping treatments (Table 3). These results might be attributed to the higher density of plants in intercropping plantings, in which lower light interception, water and nutrients were found than solid culture. The present results were in agreement with those stated by Ali et al. (1986) ElNaggar et al. (1991) Radwan (1993) and Thorsted et al. (2006). On the contrary, the intercropped wheat plants were significantly superior for plant height (in both seasons) and H.I (in the first season), compared with the solid wheat plantings (Table 3 ). The increase in plant height for intercropping treatments might be attributed to the shading and competition among wheat and faba bean plants effects in dense population for light, which caused an increase in some growth substances, such as auxins and, consequently, more plant elongation produced compared with solid wheat culture. Similar findings were reported by Abd El-Gawad et al. (1986), Radwan (1993) and Abou-Kerisha et al.(2008). 


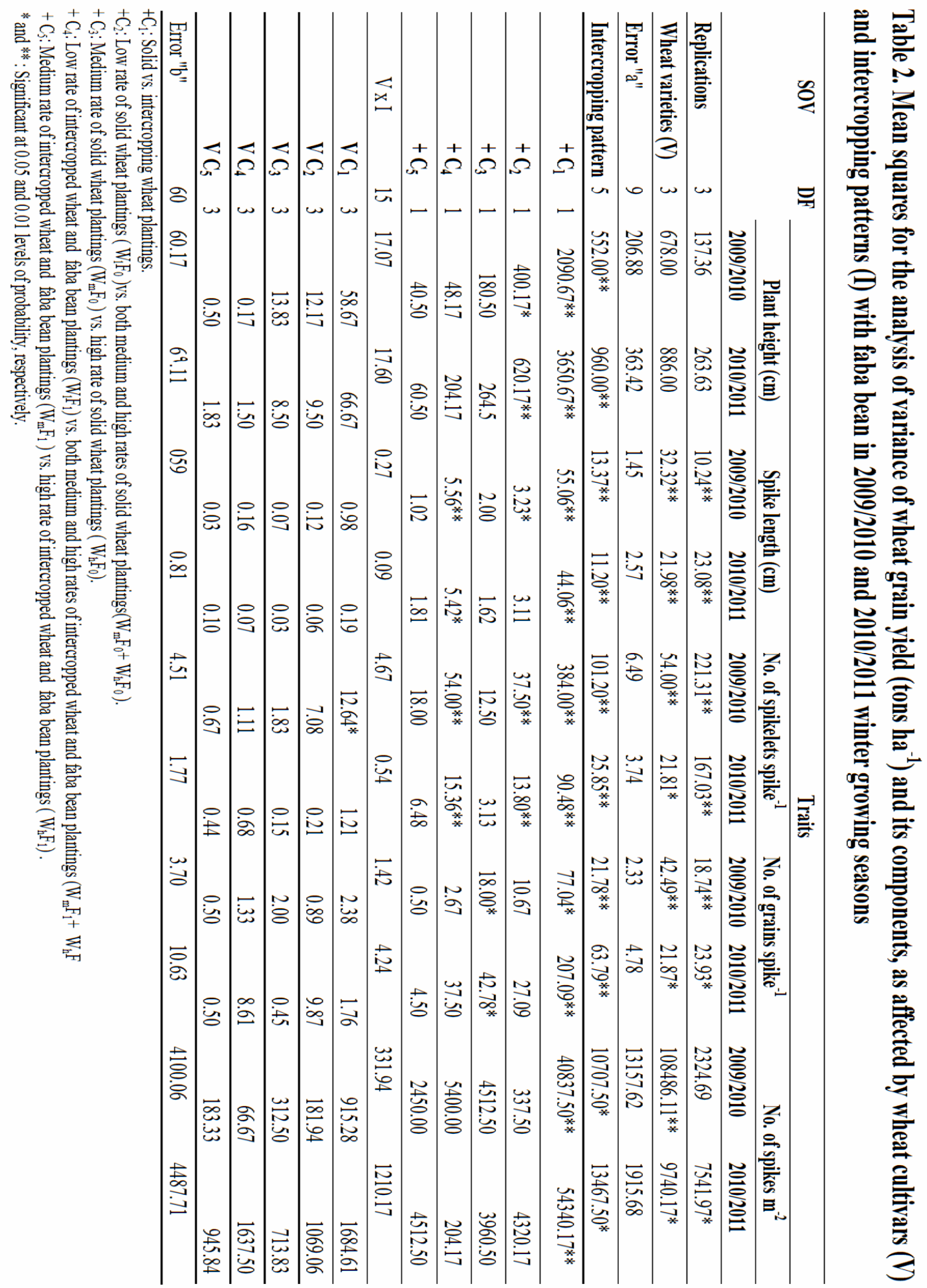




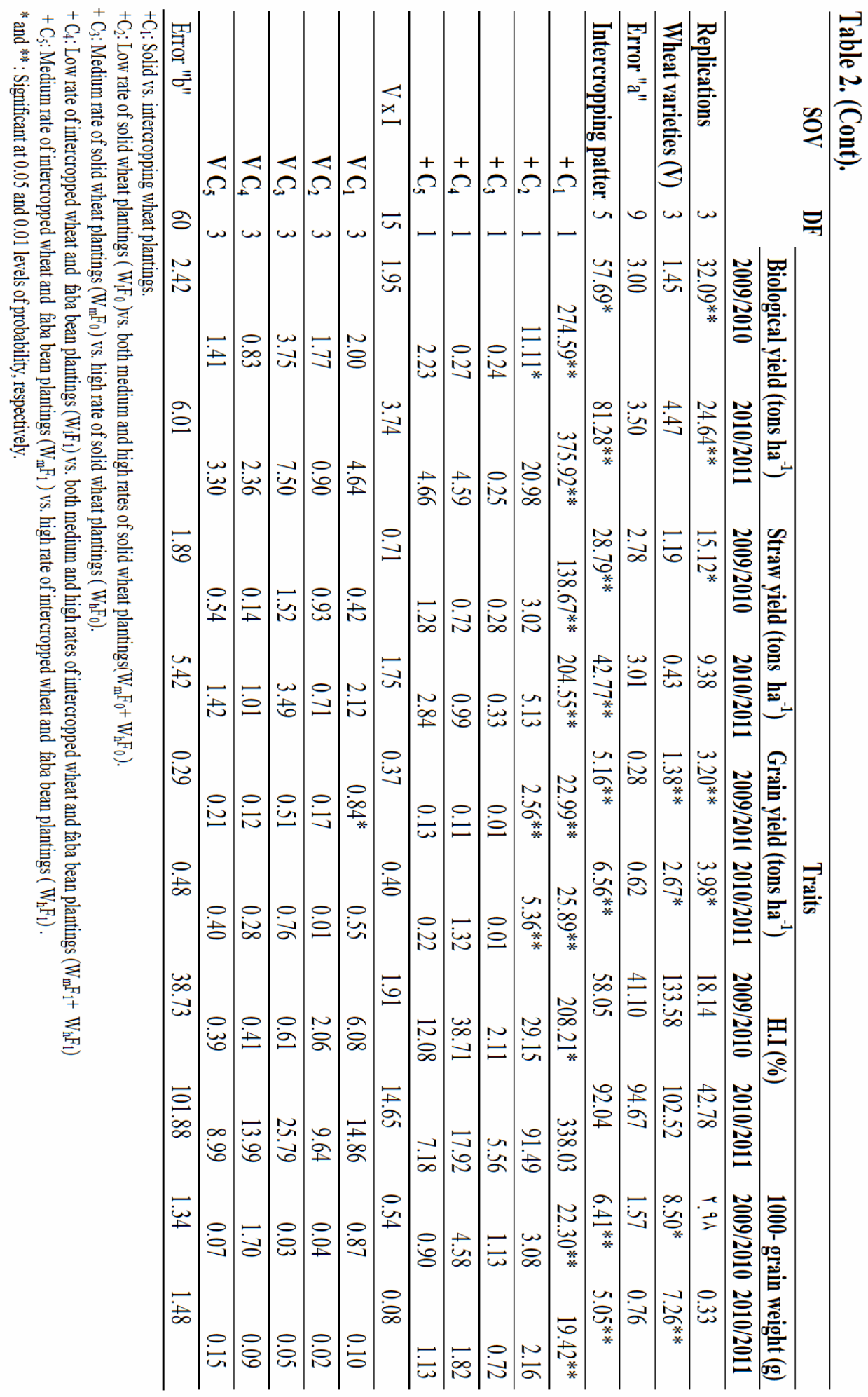




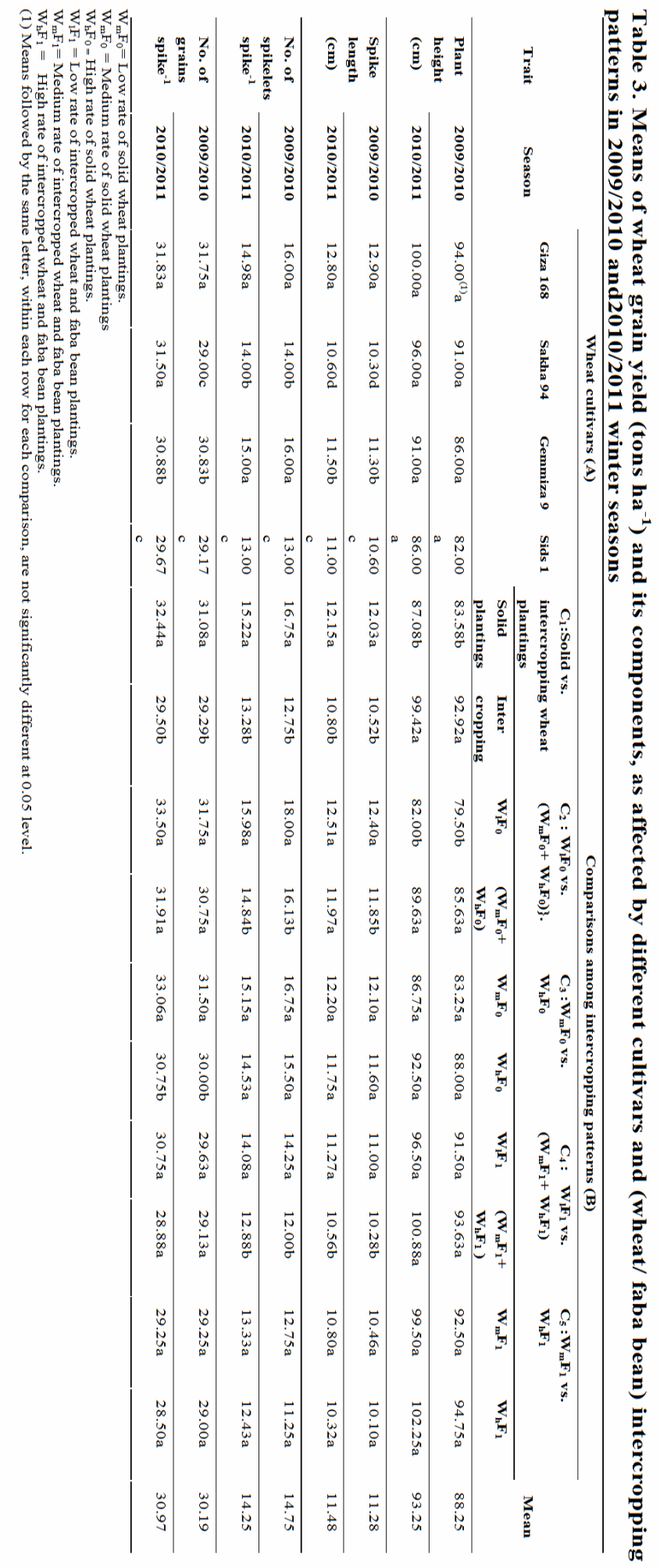




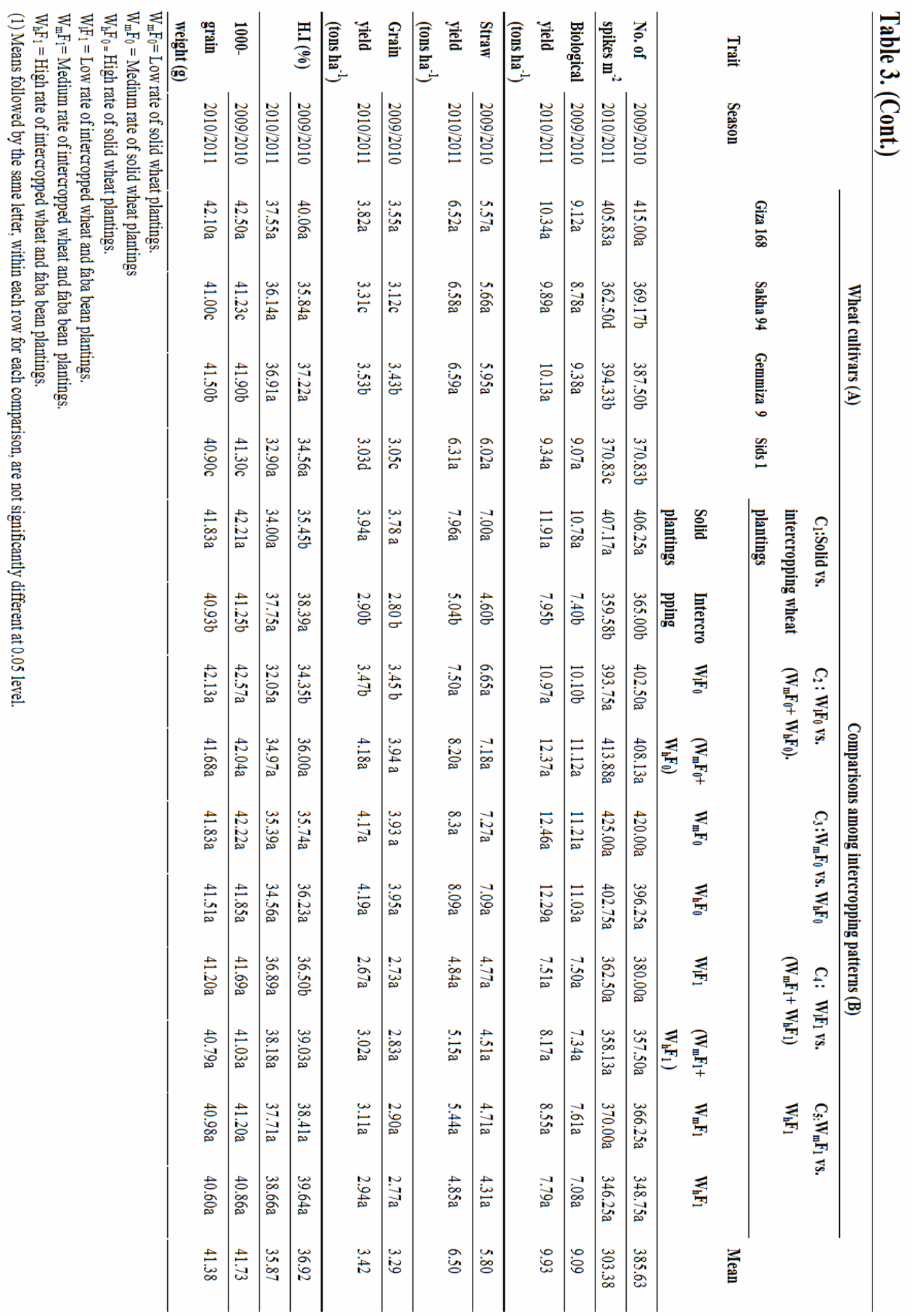


Respecting the second comparison, $\mathrm{C}_{2}$; i.e., low density of solid wheat plantings $\left(\mathrm{W}_{1} \mathrm{~F}_{0}\right)$ vs. both the medium and high densities of solid wheat plantings $\left(\mathrm{W}_{\mathrm{m}} \mathrm{F}_{0}+\mathrm{W}_{\mathrm{h}} \mathrm{F}_{0}\right)$, data in Table (2) revealed that some studied traits were insignificantly affected by increasing seeding rates of wheat plantings more than 300 grains $\mathrm{m}^{-2}$;i.e., number of grains spike $\mathrm{e}^{-1}$, number of spikes $\mathrm{m}^{-2}$, straw yield $\mathrm{ha}^{-1}$, H.I(\%) and 1000-grain weight (in both seasons), spike length and biological yield $\mathrm{ha}^{-1}$ traits (in the second season). Meanwhile, increasing seeding rate of wheat more than 300 grains $\mathrm{m}^{-2}$ significantly affected some traits; namely, plant height, grain yield $\mathrm{ha}^{-1}$ and number of spikelets spike $^{-1}$ (in both seasons), biological yield $\mathrm{ha}^{-1}$ and spike length (in the first season). Furthermore, both spike length (in the first season) and number of spikelets spike ${ }^{-1}$ traits (in both seasons) were significantly decreased with increasing seeding rate for wheat plantings more than 300 grains $\mathrm{m}^{-}$ 2 (Table 3). These results could be attributed to decreasing of competition among wheat plants under the studied low rate $\left(300\right.$ grains $\mathrm{m}^{-2}$ ) for water, nutrients and light, compared with the higher seeding rates of (350 and 400 grains $\mathrm{m}^{-2}$ ).

Regarding the third comparison, $\mathrm{C}_{3}$; viz., the medium density of solid wheat plantings vs. the high density of solid wheat plantings $\left(\mathrm{W}_{\mathrm{m}} \mathrm{F}_{0}\right.$ vs. $\left.\mathrm{W}_{\mathrm{h}} \mathrm{F}_{0}\right)$, data in Table(2) indicated that significant differences between both treatments for the number of grains spike ${ }^{-}$ ${ }^{1}$ (in both seasons). Increasing seeding rate from 350 to 400 grains $\mathrm{m}^{-2}$ significantly decreased the number of grains spike ${ }^{-1}$ from 32.3 to 32.0 as averages in both seasons (Table 3 ). These results might be due to the favorable utilization of available environmental resources for plants under the medium density of solid wheat plantings, compared with the high one. In this concern, Ghanem and El-Khawaga(1991) and Mohamed (1997)found that increasing seeding rates led to decreasing the number of spikelets spike ${ }^{-1}$, while, Mosalem (1993) found that the number of spikelets spike $^{-1}$ was not significantly affected by increasing seeding rates.

With respect to the fourth comparison $\left(\mathrm{C}_{4}\right)$; namely, the low density of intercropped wheat with faba bean plantings vs. both the medium and high densities of intercropped wheat with faba bean plantings $\left\{\mathrm{W}_{1} \mathrm{~F}_{1}\right.$ vs. $\left.\left(\mathrm{W}_{\mathrm{m}} \mathrm{F}_{1}+\mathrm{W}_{\mathrm{h}} \mathrm{F}_{1}\right)\right\}$, the results revealed significant differences for spike length and number of spikelets spike $^{-1}$ traits in both seasons (Table 2). Intercropped wheat with faba bean, by planting wheat at seeding rate of 300 grains $\mathrm{m}^{-2}$ significantly increased both spike length (from 10.42 to $11.14 \mathrm{~cm}$ ) and number of spikelets spike ${ }^{-1}$ (from 12.44 to 14.17), averaged in the two studied seasons, compared with intercropped wheat with faba bean by wheat planting with the higher seeding rates; i.e., 350 and 400 grains $\mathrm{m}^{-2}$ Table (3). It is clear that the seeding rates of wheat and faba bean, in the mixture, were adjusted below their full rate. If full rate of each crop was planted, neither would yield well because of intensive over crowding. By reducing the seeding rate of each crop, there would be have a chance to yield well within the mixture.

Concerning the fifth comparison, $\mathrm{C}_{5}$; namely, the medium density of intercropped wheat with faba bean plantings (350 grains $\left.\mathrm{m}^{-2}\right)$ vs. the high density of intercropped wheat with faba bean plantings (400 grains $\mathrm{m}^{-2}$ ); i.e., $\mathrm{W}_{\mathrm{m}} \mathrm{F}_{1}$ vs. $\mathrm{W}_{\mathrm{h}} \mathrm{F}_{1}$, it is clear that intercropped wheat with faba bean by seeding wheat at 400 grains $\mathrm{m}^{-2}$ insignificantly decreased all studied traits ( in both seasons), except for both plant height and harvest index traits, compared with intercropped wheat with faba bean by seeding wheat at 350 grains $\mathrm{m}^{-}$ 2 (Table3). Since harvest index is the grain yield/biological yield ratio, it is logically to say that, if both nominator and denominator increase and/or decrease together, the ratio, then, will be slightly changed.

It seems evident that the optimum planting seeding rates for wheat, in pure stand and intercropping with faba bean, under the studied conditions, were 400 and 350 grains $\mathrm{m}^{-2}$, respectively. This finding might be due to the lower intraspeceific competition for the edaphic and above ground environmental resources, especially light. This, in turn, resulted in an increase in grain yield components and, finally, in producing more grain yield $\mathrm{ha}^{-1}$.

\section{C- (Varietiesx intercropping patterns)interaction effects:}

Table (2) shows that the effect of interaction between the studied four wheat cultivars and the six intercropping patterns was statistically insignificant for all studied traits, in both seasons, except for both number of spikelets spike ${ }^{-1}$ and grain yield $\mathrm{ha}^{-1}$, in the first season. These results indicated that all studied traits, except for the two latter traits, showed similar response to the six intercropping patterns with the four wheat cultivars. On the other hand, the significant interaction $\left(\mathrm{VxC}_{1}\right)$ recorded for the number of spikelets spike $^{-1}$ and grain yield $\mathrm{ha}^{-1}$, in the first season, indicated that both studied factors; i.e., wheat cultivars and intercropping patterns, were not independent in their effect on these traits. The highest means for the number of spikelets spike ${ }^{-1}$ and grain yield ha ${ }^{-1}$ were obtained by solid sowing of wheat cultivar Giza 168, while, the lowest mean for grain yield $\mathrm{ha}^{-1}$ was recorded with Sakha 94 wheat cultivar when interplanted with faba bean. Regarding the number of spikelets spike ${ }^{-1}$, both 
Table 4. Means number of spikelets/ spike and grain yield $\mathrm{ha}^{-1}$ for wheat plant, as affected by the wheatvarieties and intercropping patterns $\left(V_{x} C_{1}\right)$ in 2009/2010season

\begin{tabular}{|c|c|c|c|c|c|}
\hline \multirow[b]{2}{*}{ Trait } & \multirow[t]{2}{*}{ Intercropping patterns(I) } & \multicolumn{4}{|c|}{ Wheat varieties $(V)$} \\
\hline & & Giza 168 & Sakha 94 & Gemmiza 9 & Sids 1 \\
\hline \multirow{3}{*}{$\begin{array}{c}\text { Number of } \\
\text { spikelets spike }^{-1}\end{array}$} & Solid plantings of wheat & 18.67 & 16.00 & 18.33 & 14.00 \\
\hline & Intercropping & 13.33 & 12.00 & 13.67 & 12.00 \\
\hline & $\begin{array}{l}\text { L.S.D } D_{(0.05)} \text { for the two levels of (I) } \\
\text { under the same wheat cultivar }\end{array}$ & \multicolumn{4}{|c|}{2.13} \\
\hline \multirow{3}{*}{$\begin{array}{l}\text { Grain yield } \\
\text { tons ha }\end{array}$} & Solid plantings of wheat & 2.12 & 1.86 & 1.90 & 1.68 \\
\hline & Intercropping & 1.43 & 1.26 & 1.53 & 1.38 \\
\hline & $\begin{array}{l}\text { L.S.D } \\
\text { (I) under the same the twe levels of } \\
\text { ultivar }\end{array}$ & \multicolumn{4}{|c|}{0.55} \\
\hline
\end{tabular}

Sakha 94 and Sids 1 wheat cultivars gave the lowest means when interplanted with faba bean (Table 4).

\section{CONCLUSION}

Intercropping Sakha 1 faba bean cultivar at 166667 plants ha ${ }^{-1}$ with Giza 168 wheat cultivar seeded with the rate of 350 grains $\mathrm{m}^{-2}$ in $(1: 1)$ alternate rows, $20 \mathrm{~cm}$ apart, under El-Bostan Region conditions, could be advised to obtain a high productivity of wheat.

\section{REFERENCES}

Abdel Ghaffar, A. (1994). The producing, pricing and marketing policies of wheat in the Government of Egypt. Cairo. Mimeo. (Cited after, Aboushal and Mahmoud, 2009).

Abd El-Gawad, A.A., A.E.El- Tabbakh, A.S. Edris and A.M. Abo-Shetaia. (1986). Potential productivity of wheat in Egypt. VIII. Effect of seeding rates on yield and its components. Annals Agric. Sci. 31(2):1173-1182, Fac.Agric. Ain Shams Univ., Egypt.

Abd El-Gawad, A.A., A.S. Edris and A.M. Abo-Shetaia. (1988).Intercropping faba bean with wheat.3. Inter- and intraspeceific competition among faba bean and wheat plants. Annals Agric. Sci. 33(2):1015-1029, Fac.Agric. Ain Shams Univ., Egypt.

Abdel-Hameed, I.M.(2002).Effect of some agronomic practices on wheat. Ph. D. Thesis, Fac. of Agric., Zagazig Univ., Egypt.

Abdel-Hameed, I.M.(2005). Response of two newly released bread wheat cultivars to different nitrogen and phosphorus fertilizer levels. Proceed. $1^{\text {st }}$ Sci. Conf.Creal Crops, June $20-21$, Alex. J. Agric. Res. 50(2B): 63 - 77, Special Issue, Egypt.

Abou-Kerisha,M.A., R.A.Gadallah and M.M.A.Badr. (2008). Effect of preceding and intercropping crops on yield and yield components of wheat. Minufiya J.Agric. Res. 33(3):709-728, Egypt.

Aboushal, A.A. and I.I. Mahmoud. (2009). Assessment of salinity tolerance of some wheat genotypes irrigated with saline waters. J.ADV. Agric. Res. 14 (1):195-214 (Fac.Agric. Saba Basha), Egypt.
Ali, A.A.M., M.G. Mosaad, N.F. Dawla and M.M.Kalifa. (1986). Feasibility of intercropping wheat (T. durum Def.) with field bean (Vicia faba L.) under different cultural practices. Annals Agric. Sci. 24(2):727-747 Moshtohor, Zagazig Univ., Egypt.

Ali, A.G.A., O.E. Zeiton, A.H. Bassiuny and A.Y.A. El-Bana. (2004). Productivity of wheat cultivars grown at ElKhattara and El-Arish under different levels of planting densities and $\mathrm{N}$ fertilization. Zagazig J. Agric. Res. 31(4A):1225-1256, Egypt.

Badran, M.S.S. (2009). Effect of different late sowing dates and seeding rates on productivity of some Egyptian wheat cultivars in newly cultivated sandy soils. J. Agric. Sci. 34(3):1541-1557 Mansoura Univ., Egypt.

Darwish, G.G., A.A. Tantawy, A.E.A. Ismail and O.M.M. Mobarak. (2008). Effect of sowing methods, NFertilization (Bio and mineral) and some weed control treatments on wheat productivity. Minia J. of Agric. Res. \& Develop. 28(5): 851-874, Egypt.

El-Eryani, A.A.(1995).Effect of management systems on several wheat genotypes productivity. M.Sc. Thesis, Fac. of Agric., Alex. Univ., Egypt.

El-Genbeehy, M.M.(1994). Response of field grown wheat to biofertilizer and nitrogen fertilization. Com.in Sci. and Dev. 48:25-42, Egypt.

El-Metwally,A.E., W.A.El-Murshedy andG.O. Mahmoud. (2002). Productivity of wheat and faba bean under different intercropping systems. J.Agric. Res. 28(2):312326, Tanta Univ., Egypt.

El-Monufi,M.M.(1984). Studies on intercropping wheat with various crops. Ph.D Thesis, Fac., Agric.,Al-Azhar Univ., Egypt.

El-Naggar, S.M., M.E.A.Haggag, Z.A.Nofal and M.R.Ramadan. (1991). Effect of intercropping berseem on barley and wheat. A. Growth and yield. Egypt J. Appl. Sci. 6(4):92- 112, Egypt.

Ghanem, S.A.I. and A.A.H. El-Khawaga. (1991). Growth, yield and its attributes of wheat as influenced by seeding rates and chemical weed control. ZagazigJ.Agric. Res. 18(5):1403-1416, Egypt. 
Hassan,R.K.(2003). Effect of drought stress on yield and yield components of some wheat and Triticale genotypes. Annals Agric. Sci. 48:117-129. Ain Shams Univ., Egypt.

Mohamed, A.A.E. (1997). Effect of seeding rate and nitrogen levels on bread wheat cultivars (Triticum aestivum L.). J. Agric. Res.23 (4):359-368, Tanta Univ., Egypt.

Mosalem, M.E.(1993). Response of two wheat cultivars to nitrogen levels and seeding rate. J. Agric. Res. 19(4):791805, Tanta Univ., Egypt.

Moussa, A.M.M. (2001).Sowing methods, seeding rates and nitrogen fertilization on productivity of some wheat cultivars. Ph. D. Thesis, Fac. of Agric. Kafr El-Sheikh, Tanta Univ., Egypt.

Piper, C.S. (1950).Soil and Plant Analysis. Interscience Publishers Inc., New York, pp.151- 172,USA.

Radwan,F.I.(1993). Yield and yield attributes of wheat and faba bean as affected by different intercropping patterns and nitrogen fertilization. Egypt J.Appl.Sci. 8(11): 859881.

Rowntree, J. (1993). Marketing channels and price determination for agricultural commodities. In. The Agriculture of Egypt, ed.E.M.Craig .Oxford, U.K., Oxford University Press (Cited after, Aboushal and Mahmoud, 2009).

Shalaby, E.E., M.M.El-Genbeehy and M.H.El-Sheikh. (1992). Performance of wheat genotypes under drought stress .Alex. J.Agric. Res.37:33-51. Egypt.
Shalaby, E.E., M.S.S.Badran and M.Z.D.Ahmad. (2009). Effect of surface water irrigation intervals and $\mathrm{N}$ fertilization on productivity of two Egyptian wheat cultivars under newly reclaimed lands conditions. J.Adv.Agric.Res. 14 (1):137-156 Fac.Agric. Saba Basha. Egypt.

Saleh, M.E.(2000). Effect of seeding rate on yield, yield components and some agronomic characters of two wheat cultivars. J. Agric. Sci. 25(3):1467- 1473 Mansoura Univ., Egypt.

Saleh, M.E. (2003).Response of Egyptian and Mexican wheat cultivars to different nitrogen fertilization levels under U.A.E. conditions. Zagazig J.Agric.Res. 30(4):1189-1201.

Saleh, M.E., A.A.G.Ali and I.E. Ramadan. (1986). Yield and yield components of intercropped wheat with faba bean in various intercropping systems. Agron.Alex. (1): 635647, Egypt.

Steel, R.G.D and I. N. Torrie. (1980). Principles and Procedures of Statistics $2^{\text {nd }}$ Edition. Mc. Graw Hill Co, New York, USA.

Tabl, M., A. M. Omar, E. El - Sheref and M. H. M . Koriem. (2005). Effect of seeding rates and nitrogen levels on two wheat cultivars. Proceed. $1^{\text {st }}$ Sci. Conf.Creal Crops, June 20-21, Alex. J. Agric. Res. 50(2B): 87 - 95, Special Issue, Egypt.

Thorested, M.D., J.E. Olesen and J.Weiner. (2006). Width of clover strips and wheat rows. Influence of grain yield in winter wheat/ white clover intercropping. Field Crop Res. 95:280-296. 


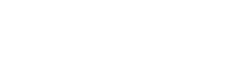

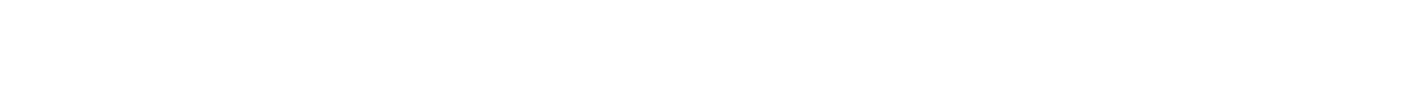

[مدصبهيسعد بنرل

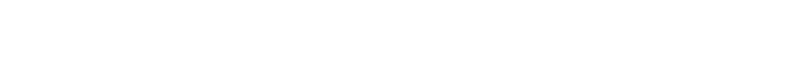

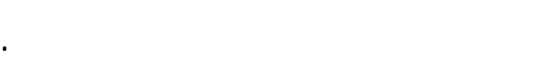

كلت الفروق الاهصائه معنوية بـ زراكة القمح منفردا بلستخدم

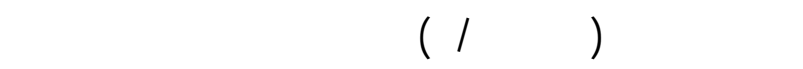

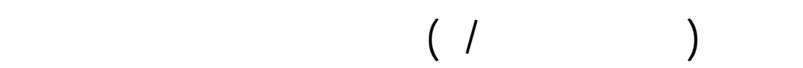

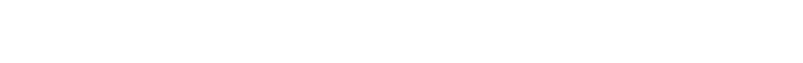

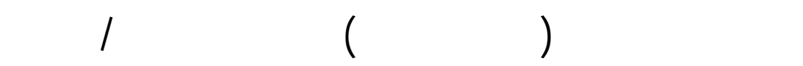

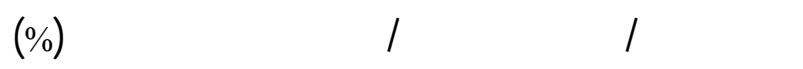
ووزن الألف حة (جم) وذلك \ـ كلاموي الدرلية.

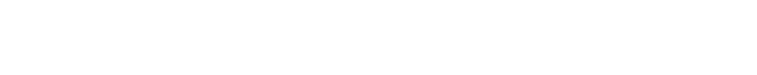

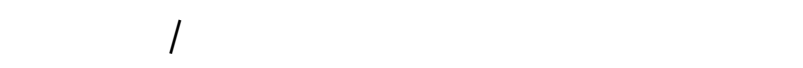

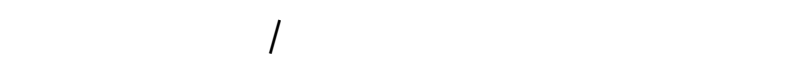

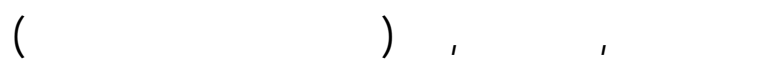

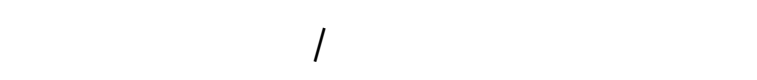

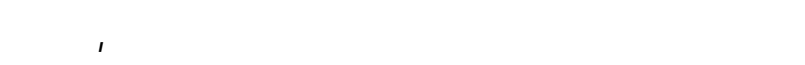

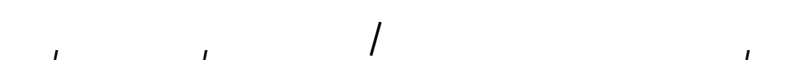

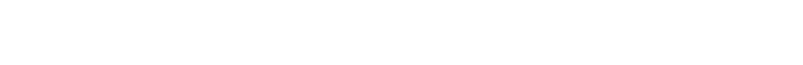

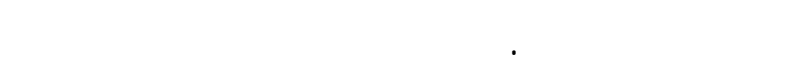

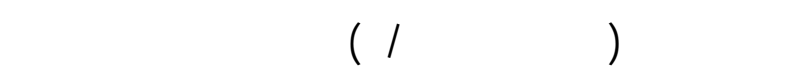
الصفلت إلمروية بذلك.

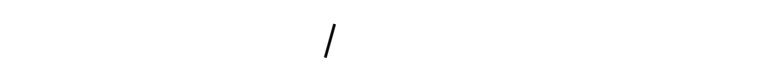

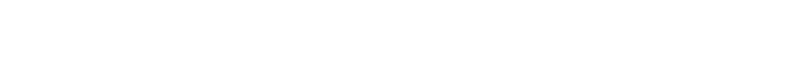
كلامويل الدرلة بلسشناءصفل: ارتفاع النبلت ومعلل الصصاد

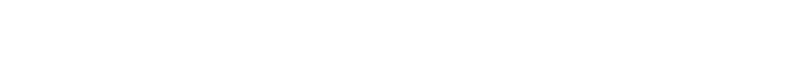
حبه

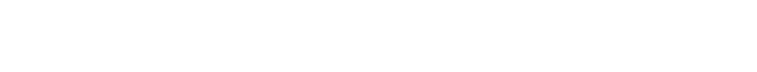

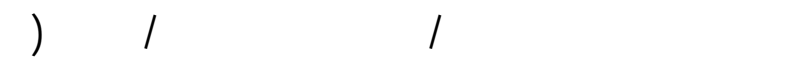
(آلمuم الأول).

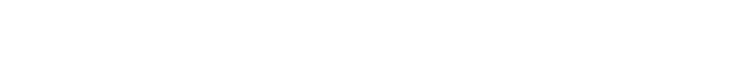

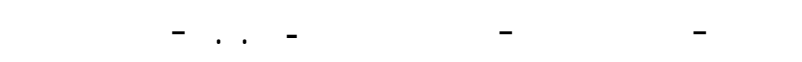

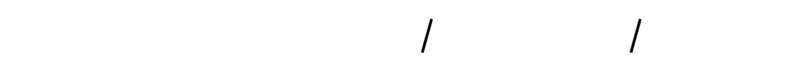

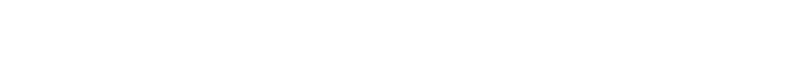

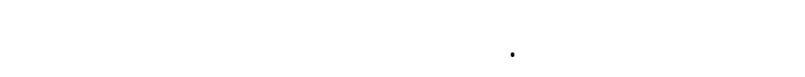

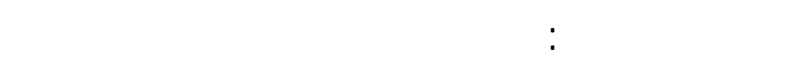

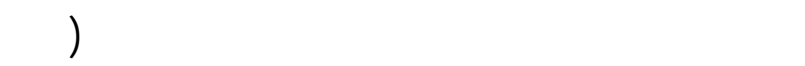

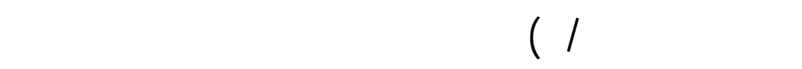

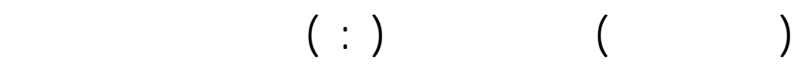

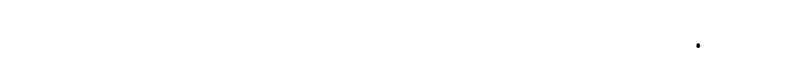

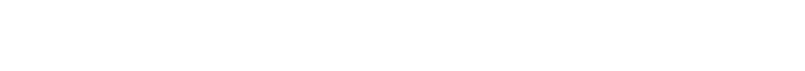

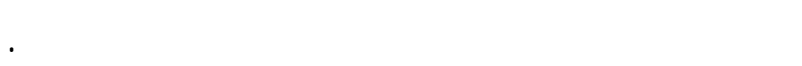
وكاكن تلخصص أهم تنائج هذه الدرلسة على النحو الاتى: -

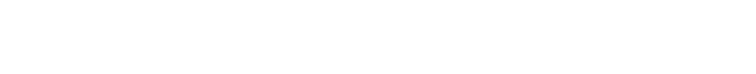

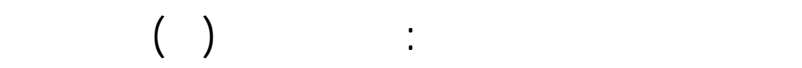

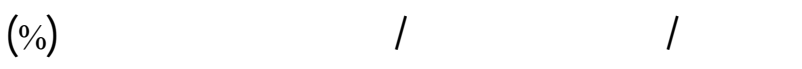

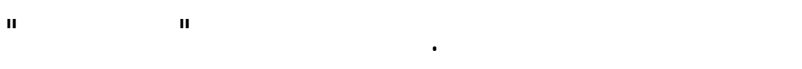

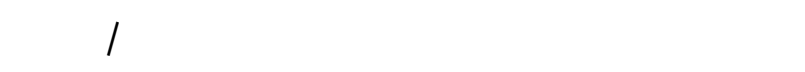
وكذا الصفلت إصولية:طول المنبلة(سم) وعدد الـبوبالمد نبله

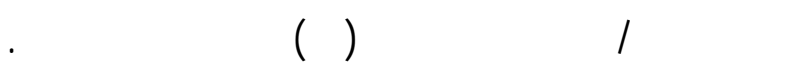

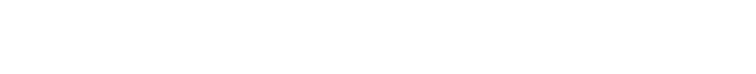

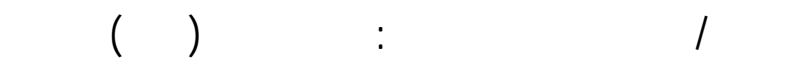

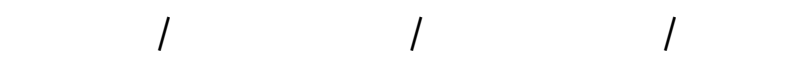

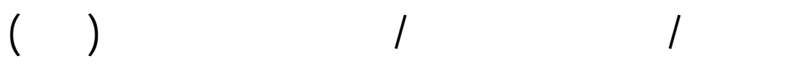

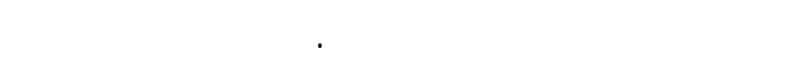

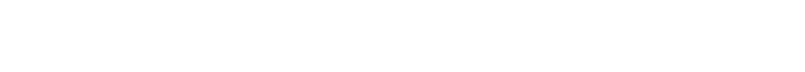

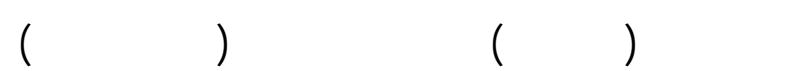




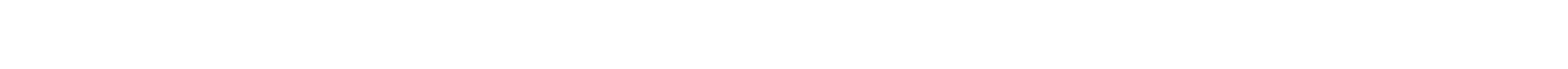

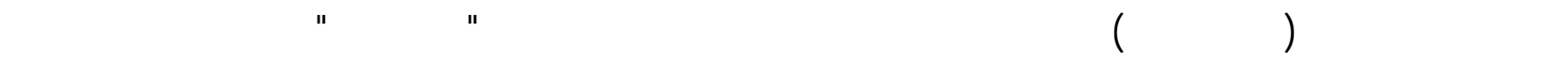

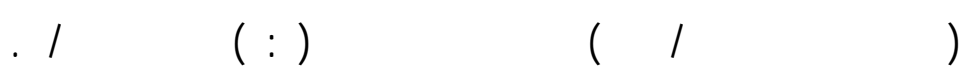

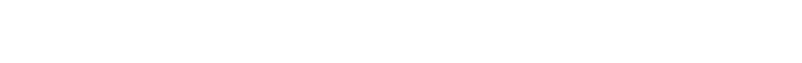

